To appear in Joseph Shimron (ed.) Processing and Acquisition of Semitic

Morphology. Amsterdam \& Philadelphia: John Benjamins

\title{
The Formation of Ethiopian Semitic Internal Reduplication *
}

\author{
Sharon Rose \\ University of California, San Diego
}

\section{Introduction}

Semitic word formation has proved particularly contentious over the past several years with respect to the notion of the 'root' and 'template'. While traditional grammarians viewed Semitic words as consisting of roots and patterns (involved in paradigmatic relations), this approach has proved insufficient for certain kinds of word-formation that appear to require correspondence between words, such as the relationship between singular nouns and broken plurals (Ratcliffe 1998). In modern approaches to Semitic morphology, we can recognize the following basic divisions:

(1) a. Root-and-pattern morphology - a root is associated with a template; the template coordinates vowel melodies and consonant positions

b. Word-based morphology - words are formed from independent words; templates act as constraints or filters on vowel/consonant combinations or as independent morphemes

The first type represents a morpheme-based theory, and within the generative autosegmental literature, received a thorough exposition in McCarthy (1979) and subsequent work. Under this approach, the template is viewed as a separate morpheme consisting of syllabic (or later moraic) positions to which a root is mapped (McCarthy 1979, 1981), or as a representation containing vowels or information on consonant clustering (e.g. Goldenberg 1994). Importantly, the 'root' is recognized as a discontinuous lexical entry distinct from the template (see Prunet, Béland \& Idrissi 2000 for compelling external evidence for the root in Arabic). This approach has also been adopted for many analyses of Ethiopian Semitic languages (e.g. Angoujard 1988, Banksira 1997, 2000, Buckley 1990, Chamora 1997, Prunet 1996a,b, Rose 1997).

The second type of word-formation is recognized for words that are closely connected to independent words both semantically and phonologically, such as broken plurals. Broken plurals are clearly related to their singular counterparts, but not necessarily to other words, such as verbs (Angoujard \& 
Denais 1989, Hammond 1988, McCarthy \& Prince 1990a, Ratcliffe 1998). For example, the Tigre singular məskot 'window' corresponds to the plural masa:kut 'windows'. Hammond (1988) recognized that since the form of the plural is dependent on that of the singular, Arabic broken plurals constituted a problem for the root-and-pattern derivation proposed in McCarthy (1979) in which each template is independently selected and associated with a root. Although analyses matching the singular to the plural were proposed using plural templates (e.g. McCarthy \& Prince 1990a), the notion of the 'root' in broken plural formation was not explicitly rejected in generative literature until Ratcliffe (1998). Rejection of the root has also been espoused by researchers such as Bat-El (1994) and Ussishkin (1999), based on Hebrew denominal verbs, a class of words that also bear properties of corresponding nouns, such as consonant clustering effects. Since these output-based word formation patterns can be analyzed with no reference to the root, these analysts have concluded that the root does not exist as a morphological unit. Heath (1987), Ratcliffe (1997), Benmamoun (1999) and Ussishkin (2000a,b) have argued that verb formation, one of the hallmarks of root-based morphology, is word-based rather than rootbased, although they differ on which verb form serves as the base (cf. McCarthy \& Prince 1990b for word-based verbal derivation that still acknowledges the root). Analysts also differ in their degree of rejection of the root. Theoretical arguments offered against the root include a desire for theoretical 'simplicity' (Ratcliffe 1997, 1998) or to emphasize that Semitic languages are 'less exotic with respect to their morphology' than other languages (Ussishkin 2000a) Ratcliffe (1998:50) argues that "[s]ince the theory now recognizes that some derivations must operate on words, it is preferable to assume that derivational rules are in all cases operations on words. This would imply that (phonologically possible) words rather than three-consonant roots are the primitive lexical entries of the Arabic lexicon".

In this paper, I discuss data from another type of word formation process in Ethiopian Semitic languages ${ }^{1}$ that also appears to be word-based rather than root-based. Ethiopian Semitic verbs have a form of internal reduplication, often termed the 'frequentative', which appears to be formed by infixing a 'reduplicative syllable' into a regular verb stem. The reduplicative syllable consists of reduplication of the penultimate stem consonant and a vowel, usually [a] ([a:] in Tigre, and sometimes [ə] in Gurage dialects such as Chaha), as shown in (2). There is a clear semantic correlation between the frequentative and the regular form of the verb. Data in this article are drawn from Tigre and Tigrinya, North Ethio-Semitic languages, and from Harari, Amharic, Chaha (Gurage) and Muher (Gurage), all South Ethio-Semitic. ${ }^{2}$

$\begin{array}{lllll} & \text { Regular } & & \text { Frequentative } & \\ \text { Amharic } & \text { ləwwət'-ə } & \text { 'change' } & \text { ləwwawwət'- } \partial & \text { 'change constantly' } \\ \text { Tigrinya } & \text { səbər-ə } & \text { 'break' } & \text { səb̆babər-ə } & \text { 'break in pieces' }\end{array}$


Tigre safan-a: 'load' sạa:San-a: 'load a little'

Despite the apparent infixal nature of this word formation, I argue that internal reduplication is not formed simply via infixation to the corresponding regular verb (cf. Buckley 1990 for Tigrinya); but neither is there a 'frequentative' template (cf. Angoujard 1988) to which a root is mapped. Instead, the shape of the frequentative is dependent on the templatic shape of quadriliteral verbs in general, and also the root. These superimposed requirements obscure the direct relationship between the regular verb stem and the frequentative. ${ }^{4}$ I argue that the root must be referenced, even in word-based derivation, a conclusion also reached in Zawaydeh \& Davis (1999a,b) for Arabic hypocoristics, although they refer to an 'output consonantal root'. I also present evidence from South EthioSemitic languages that the root cannot be construed as a 'phonological unit' (cf. Ratcliffe 1997), but must be an independent morphological entity.

The paper is organized as follows. In $\$ 2$ I discuss the nature of frequentative formation in various Ethiopian Semitic languages. I present arguments that the frequentative in Ethiopian Semitic languages cannot be derived simply by infixation, but neither can it be derived via root and pattern morphology. In \$3 I argue for an alternate approach that combines word-based morphology with additional templatic constraints as well as crucial reference to the root.

\section{Previous approaches to the frequentative}

In most Ethio-Semitic languages, the frequentative is used to express intensive or repetitive action, as shown by the following Harari forms. Speakers often give the qualifier 'a lot' or 'again' when describing the meaning of these verbs:

\begin{tabular}{|c|c|c|}
\hline \multicolumn{3}{|l|}{ Harari } \\
\hline Regular & & Frequentative \\
\hline kətəf-a & 'chop' & kitatəf-a 'chop a lot' \\
\hline k'əbəl-a & 'decrease' & 'decrease greatly' \\
\hline lak' ət'-a & 'mix' & lik'ak'ət'-a 'mix a lot' \\
\hline magəd-a & 'burn surface, annoy, pain' & migagəd-a 'burn a lot' \\
\hline
\end{tabular}

However, despite this tendency, there is still a range of meanings that the frequentative may adopt, often dependent on the meaning of the base verb. Leslau (1939) describes the semantic value of the frequentative as reiterative, intensive, augmentative or attenuative, to which one could add distributive. In Tigre, the meaning is commonly diminutive (Rose to appear). See also Leslau (1995) for a list of meanings in Amharic. 
Two analyses have been presented in the literature for the formation of the frequentative: the infixation hypothesis, a word-based derivation, and the template hypothesis, a root-and-pattern based derivation. In this section I argue that neither is adequate to capture all the complexities of frequentative formation.

\section{$2.1 \quad$ Infixation hypothesis}

The identification of the reduplicative syllable suggests that the frequentative is formed by infixation of the syllable $-\mathrm{Ca}$ - (where $\mathrm{C}=$ consonant) into the regular verb, the infixation hypothesis. This is the position adopted by Buckley (1990) for Tigrinya and by (Petros) Banksira $(1993,1997,2000)$ for Chaha. While it appears on the surface to be the most natural approach, it faces several problems. First, no matter the shape of the original verb, the basic frequentative has its own specific template; gemination and the vowel pattern of the original verb are not usually maintained in the frequentative. Ethiopian Semitic verbs are classified lexically into at least three conjugation patterns, termed Types A, B and $\mathrm{C}$. These Types have specific characteristics, such as vowel patterns or gemination of the penultimate consonant, but they are not associated with a specific semantic connotation. Most Ethio-Semitic languages do not have typical binyanim like Hebrew or Arabic; causative and passive/reflexive prefixes do engender internal stem changes. Type $\mathrm{C}$ is characterized in all the languages by a vowel [a] ([a:] in Tigre) between the first two consonants. Type B is characterized by gemination of the penultimate consonant in all verb forms in those languages that allow gemination. ${ }^{5}$ Type $\mathrm{A}$ has gemination of the penultimate consonant in the imperfective in North Ethio-Semitic (Tigre and Tigrinya), but in the perfective in South Ethio-Semitic. All Types have different jussive/imperative templatic patterns, ex. Tigre Type A li-dgam, Type B $l i$ wallib, Type C li-ba:rik. The lack of correspondence between the templatic shape of regular verbs and the shape of the frequentative is illustrated for Tigre in (4).

$\begin{array}{lllll} & \text { Tigre } & \text { Regular } & \text { Frequentative } & \\ \text { a. Type A } & \text { dəgm-a: } & \text { dəga:gəm-a: } & \text { 'tell' } \\ \text { b. Type B } & \text { wəlləb-a: } & \text { wəla:ləb-a: } & \text { 'look both ways' } \\ \text { c. Type C } & \text { ba:rək-a: } & \text { bəra:rək-a: } & \text { 'bless' }\end{array}$

The consonant cluster seen in the $3 \mathrm{~ms}$ form of Type A verbs in Tigre is not maintained in the $3 \mathrm{~ms}$ frequentative. The gemination of Type $\mathrm{B}$ is also not maintained, nor is the [a:] vowel of Type $\mathrm{C}$. 
In Harari and Chaha, the first vowel [ə] of regular Type A and B verbs is replaced with an epenthetic vowel ([i] and [i] respectively) in the frequentative, mirroring the pattern of regular quadriliterals, e.g. Harari gilabat-a / Chaha misəkar-ə-.

$\begin{array}{lll}\text { Regular } & \text { Actual } & \text { Predicted } \\ & \text { Frequentative } & \text { Frequentative } \\ \text { kətəf-a } & \text { kitatəf-a } & \text { *kətatəf-a 'open' } \\ \text { kətəf-ə- } & \text { kitatəf-ə- } & \text { *kətatəf-ə- 'open' }\end{array}$

Amharic jussive forms demonstrate the same basic problem. If the frequentative were formed by infixing a syllable to the jussive form, we would predict the incorrect forms in (6) for the jussive. Note that although the Type B verb yifalallig with gemination is possible for some speakers, simple insertion cannot generate the other possible form without gemination:

(6)

\begin{tabular}{lllll} 
Amharic & Regular & Actual & \multicolumn{2}{l}{$\begin{array}{l}\text { Predicted } \\
\end{array}$} \\
Type A & yi-sbər & Frequentative & Frequentative & \\
Type B & yi-fəllig & yi-səbabir & *yi-sbabər & 'break' \\
Type C & yi-bark & yi-bərarik & ?yi-fəlallig & 'want' \\
& & ?yi-bararik & 'bless'
\end{tabular}

The second argument against straightforward infixation comes from quadriliteral verbs. The quadriliteral forms the frequentative with reduplication and [a], producing a verb with five consonants. This is possible in all languages examined except Chaha.

\begin{tabular}{|c|c|c|c|c|}
\hline & Regular & Actual & Predicted & \\
\hline & dəngəs'-a: & $\begin{array}{l}\text { Frequentative } \\
\text { dənəga:gəs'-a: }\end{array}$ & $\begin{array}{l}\text { Frequentative } \\
\text { *dənga:gəs'-a: }\end{array}$ & \\
\hline & məskər-ə & məsəxaxər-ə & *məskaxər-ə & 'testify' \\
\hline 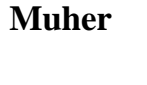 & sinəzzər-ə- & sinzazzər-ə- & *sinəzazzər-ə- & $\begin{array}{l}\text { 'raise arm } \\
\text { to strike' }\end{array}$ \\
\hline$a r$ & dinəbət'-a & dinbabət'a & $*$ dinəbabət'-a & 'be scared' \\
\hline
\end{tabular}

If the reduplicative syllable were simply infixed into the regular verb, we would expect the derivation /dəngəs'-a + Ca:/ --> *dənga:gəs'a for Tigre (and Tigrinya), but the actual five-consonant form has an extra vowel [ə] intervening between the second consonant and the reduplicated consonant: dənəga:gəs'a: Muher and Harari present the opposite problem, favoring a cluster in the actual frequentative over open syllables. In conclusion, simple infixation of a 
reduplicative syllable into the regular verb cannot accurately capture all the properties of the frequentative.

\subsection{Template hypothesis}

If simple infixation to the regular verb stem does not produce the correct output forms, could the frequentative be characterized by its own template to which the root is mapped? I dub this the template hypothesis. For example, Angoujard (1988) proposes a template with the penultimate consonant position marked as a 'copy' position or an infix for Amharic. The root maps to the template and then the preceding consonant is copied to the copy position. Rose (1992) also proposes a separate frequentative template to which the root is mapped for Chaha. Petros (Banksira) \& Prunet (1996) in an analysis of special 'local movement' verbs, propose a single quadriliteral template for Chaha (CCaCC or $\mathrm{CC} ə \mathrm{CC}$ ), intended for all types of quadriradical outputs, including internal reduplication. The template hypothesis avoids the problems of the infixation hypothesis, and accounts for why the frequentative template is identical for all verb Types. However, by relying on a separate template, this analysis misses the generalization that the position and quality of the vowels is remarkably similar to those of regular quadriliterals, as shown in (8) for the roots /mskr/ 'testify' and /sbr/ 'break'.

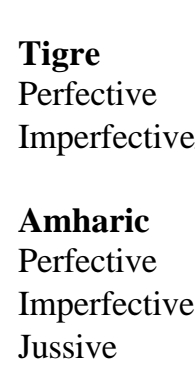

Quadriliteral

məskər-a:

li-məskir

məsəkkər

yi-məsəkkir

yi-məskir
Frequentative

səba:bər-a:

li-səba:bir

səbabbər

yi-səbabbir

yi-səbabir

The only difference between the quadriliteral and the frequentative templates is the presence of the [a] of the reduplicative syllable. In Amharic, gemination occurs in the perfective and imperfective of both the regular quadriliteral and the frequentative, but not in the jussive. The perfective forms have a vowel [ə] between the two final consonants, whereas the imperfective and the jussive do not. Again, apart from the presence of the vowel [a] between the second and third consonants in the frequentative, and the vowel [ə] or no vowel in the quadriliteral, the forms are identical. ${ }^{6}$ If the frequentatives had completely separate templates, their similarities with quadriliterals would be entirely accidental. 
A second problem with the separate template analysis is that two different frequentative templates would be necessary to accomodate those frequentatives formed from triconsonantal forms and those derived from quadriconsonantal forms, where the subscript indicates identical consonants. Examples are repeated from Tigre.

$$
\begin{array}{lll}
\text { Triconsonantal: } & {\mathrm{C} ə \mathrm{C}_{\mathrm{i}} \mathrm{a}: \mathrm{C}_{\mathrm{i}} ə \mathrm{C}-} & \text { dəga:gəm-a: } \\
\text { Quadriconsonantal: } & {\mathrm{C} ə \mathrm{C} ə \mathrm{C}_{\mathrm{i}} \mathrm{a}: \mathrm{C}_{\mathrm{i}} ə \mathrm{C}-} & \text { dənəga:gəs'-a: }
\end{array}
$$

Finally, in Tigre, the reduplicative syllable may be repeated up to three times, each repetition conveying further attenuation of the action (Rose to appear):

$$
\begin{array}{ll}
\text { dəgm-a: } & \text { 'tell, relate' } \\
\text { dəga:gəm-a: } & \text { 'tell stories occasionally' } \\
\text { dəga:ga:gəm-a: } & \text { 'tell stories very occasionally' } \\
\text { dəga:ga:ga:gəm-a: } & \text { 'tell stories infrequently' }
\end{array}
$$

Tigre provides striking evidence that the reduplicative syllable is a salient isolable part of frequentative formation, and not a templatic syllable marked off with a diacritic as special.

\section{Templates and roots in word-based derivation}

Neither hypothesis is capable of capturing the range of frequentative properties. On the one hand, the frequentative should match the vowel quality and gemination patterns of quadriliterals, since a frequentative form also has at least four consonants. On the other hand, it must differ from a regular quadriliteral in the position of the reduplicated consonant and the accompanying [a] vowel, which form a consistent 'reduplicative syllable'. In order to capture all these properties, I propose that the frequentative is formed via infixation of a reduplicative syllable to the regular verb stem, but that the actual surface form is governed by additional requirements, requiring reference to templatic shapes and the root. These requirements obscure the overt relationship between the regular verb and the frequentative:

i. Template match

An output form with four/five root segments must conform to a quadri-/quinqui-consonantal template, matching the position and nature of the vowels 


\section{ii. Root Realization}

All root segments are represented in the output, where possible

The derivation of the frequentative from the basic stem involves associations between three lexical/morphological entities. The derivation proceeds according to a word-based infixation mechanism with reduplicative copy. But, the two requirements in (11) act as constraints on the transfer of properties from the shape of other verbs with comparable root segments and the root itself. As the basic stems are derived from the root, this model assumes that the speaker has access to information about whether the root is faithfully realized in the basic stem. If any root segments are not faithfully realized, the speaker can access the original root to recuperate them in the derivation of the frequentative. This model is shown in (12). The template match and root realization constraints are shown with dotted lines.

(12)

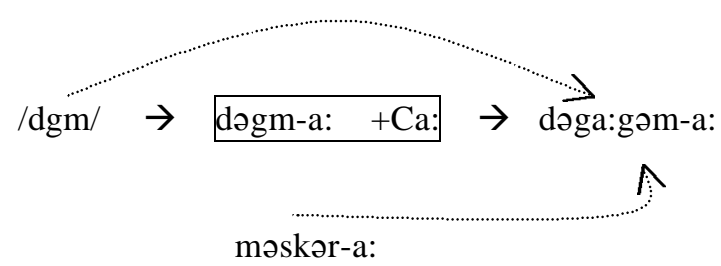

One might counter that given these requirements, reference to the regular verb form is unnecessary. However, besides the semantic connection, two morphophonological pieces of evidence argue in favor of reference to the regular verb. First, reduplicative verbs such as nəknək 'shake in hysterics' have only two root consonants $/ \mathrm{nk} /$, yet the frequentative is nəkəna:nək- 'shake in hysterics a little'. If reference were only made to the root, we might expect the frequentative to be nəka:kək- or nəka:nək-, which also match the frequentative shape. The second is actually attested as an alternate possibility for Tigrinya quadriliterals (Rose 2000), but in Tigre, this corresponds to the intensive form. Second, in some languages the frequentative optionally incorporates gemination or the vowel quality that is characteristic of the basic stem. For example, the frequentative of Type $\mathrm{C}$ verbs in Amharic may, for some speakers, have the vowel [a] in the second position: barakə 'bless' corresponds to bararraka or bararraka (Leslau 1995:456), although the Amharic speakers I consulted prefer the form with the [ə] vowel. The same is true for Tigrinya (Leslau 1941). These results demonstrate the frequentative's allegiance to the independent regular 
verb. In this manner, it is similar to other cases of derived stems in Semitic languages

\subsection{Template Match}

The first requirement in (11) involves a match between the number of segments ${ }^{7}$ in the output and the shape of the template. If an output form has four segments, no matter the source of the segments (i.e. root consonants or their reduplicants), the output must conform to a quadriliteral shape, both in the position and quality of vowels, and in consonant gemination. In North Ethio-Semitic, the quadriliteral shape is $\mathrm{C} ə \mathrm{CC} ə \mathrm{C}$ in the perfective and $\mathrm{C} ə \mathrm{CCiC}$ in the imperfective/jussive. This templatic requirement overrides the templatic shape of the regular triconsonantal verb stem. ${ }^{8}$ Template match holds for any verbs with four output consonants, including final doubling (13b), total copy (13c) and the frequentative (13d). The only difference between the other kinds and the frequentative is the [a] vowel located before the penultimate consonant in the frequentative, as shown for Tigre:

\begin{tabular}{lllllll} 
(13) & Tigre & Root & Perfective & \multicolumn{2}{l}{ Imperfective/Jussive } \\
a. Quadriliteral & mskr & məskəra & li-məskir & 'testify, witness' \\
b. Final doubling & s'nf & s'ənfəfa & li-s'ənfif & 'sip' & in \\
c. Total copy & nk & nəknəka & li-nəknik & 'shake & & \\
$\begin{array}{c}\text { hysterics' } \\
\text { d. Frequentative }\end{array}$ & grf & gəra:rəfa & li-gəra:rif & 'whip a little'
\end{tabular}

This suggests that template selection is a function of reduplication and not that reduplication is a byproduct of template selection, as argued by Prunet \& Petros (1996) for the Gurage dialect Chaha. They argue that if a root selects a 'long template', a quadriconsonantal template, then reduplication automatically follows. While this approach is appealing for the final doubling and total copy cases, it does not naturally extend to the frequentative, which, as I have argued above, cannot be explanatorily derived through template selection alone. Instead, I am suggesting that the frequentative makes use of independently required templates used for other verb forms. ${ }^{9}$

Some languages allow verbs with five consonants of the shape СəСəССəC- i.e. Tigre ћawəšwəš- $a$ :. Most of these verbs involve final reduplication and are derived from triconsonantal roots. This is a pan-Semitic pattern, as documented in Unseth (1998). Nevertheless, their conjugation patterns are systematic and mirror the quadriconsonantal shape with the addition of an extra $\mathrm{Co}$ syllable ( $\mathrm{Ca}$ if the $\mathrm{C}$ is guttural) at the left edge of the word: 


$\begin{array}{lll}\text { Tigre } & \text { 'disappear' } & \text { 'grumble' } \\ \text { perfective } & \text { hawəšwəš-a: } & \text { gərəmrəm-a: } \\ \text { imperfective/ } & \text { la-hawəšwǐs } & \text { li-gərəmrim } \\ \text { jussive } & & \end{array}$

This is the shape used by the quadriliterals to form a frequentative: masəka:kəra: / li-masəka:kir and accounts for the existence of the vowel [ə] between the second and third consonants. If the root has four consonants, languages like Tigrinya and Amharic allow reduplication to be optionally suppressed, and only the infix [a] to appear: masakər-a, in addition to masəkakər-a. For those who prefer the quinquiconsonantal template, more emphasis is placed on reduplication (Rose 2000). For those who select the quadriconsonantal template, reduplication is suppressed in favor of the shorter, more common template. There is no room for reduplication within the shorter template without deleting one of the root consonants. This is essentially a trade-off between reduplication and conforming to a quadriconsonantal frequentative shape. In each case, however, the notion of 'frequentative' is adequately expressed.

This mechanism of reference to independently occurring templatic requirements differs from other approaches to word-based derivation. Ussishkin (2000a,b) advocates Melodic Overwriting as a mechanism of deriving verbs in Modern Hebrew (see also Gafos 1998). For example, given a basic perfective verb gadal 'grow' the intensified gidel is derived by 'overwriting' the vowels of the base with affixal vowels /i e/, which are assumed to be discontinous morphemes. The 'root' is epiphenomenal, as it is simply the residue of the base remaining after overwriting. While this works neatly for Hebrew, in which there is a one-to-one match between base vowels and affix vowels, the approach faces problems when confronted with Ethiopian Semitic frequentative data. First, it alone cannot account for the loss of gemination seen with Type B verbs, ex. Tigre wallag-a: --> walalag- $a$ : Second, many of the vowels required to overwrite base vowels are epenthetic and therefore should not be included in the lexical entry. For example, in Muher, the Type B verb imperative matt'is 'break a string' corresponds to the frequentative mit'at'is. Deriving the frequentative via melodic overwriting would require overwriting [ə] with an epenthetic vowel [i]. If prefixes are added, the problem is more acute, as there is no vowel at all between the first two consonants of the stem: yə-matt'is vs. yə-mt'at'is. It is clear that melodic overwriting is not sufficient to account for the quality and position of vowels in the frequentative, as the entire templatic shape is superimposed, not just the vowels.

\subsection{Reference to the root}


The consonant which is copied in frequentative reduplication is the penultimate consonant of the regular verb. In most cases this consonant is also the penultimate root consonant. However, if the regular verb itself contains reduplication, in some cases the penultimate is the reduplicative surface correspondent of the input root consonant. In other cases, the consonant copied is not the penultimate surface consonant, but the penultimate root consonant. This occurs with weak roots containing glides, and other opaque verb forms. I now consider how these verbs pose a problem for frequentative formation unless the root is referenced. It should be noted that although these verbs are irregular, their conjugation patterns are entirely systematic.

\subsubsection{Weak roots with glides}

Medial and final glides usually surface as front vowels or round vowels unless geminated in North Ethio-Semitic, ex. Tigre dor- 'go around' (root dwr) or matt'e- 'betray' (root mt'y). ${ }^{10}$ In South Ethio-Semitic, glides may also appear as palatalization or labialization of neighboring consonants, ex. Muher nəgg ${ }^{y} \partial-$ 'dawn' (root ngy). A non-surfacing glide in a regular hollow (glide-medial) verb will be realized in the frequentative. Consider the following forms from the Tigre verb /dwr/ 'go around'.

$\begin{array}{llll} & \text { Perfective } & \begin{array}{l}\text { Imperfective } \\ \text { ti-dəwir }\end{array} & \begin{array}{l}\text { Jussive } \\ \text { ti-dur }\end{array} \\ \text { 2ms } & \text { dir-ka } & \text { li-dəwir } & \text { li-dur } \\ 3 \mathrm{~ms} & \text { dor-a } & \text { dir-dəwr-o } & \text { li-dr-o }\end{array}$

The root glide $/ \mathrm{w} /$ in the verb dor- shows up as [u], [w], as part of [o], or not at all. ${ }^{11}$ The frequentative form is dawa:war-. Under a purely word-based derivation, it is not clear what stem should serve as the base, as the perfective stem has two alternants dor-and dir-. Clearly, dor-is preferred as it contains a clue as to the underlying glide by the presence of the vowel [o]. Yet, it is not clear how this would be selected. Other 3masc.sg. stems contain less information about glides than 2 masc.sg. stems. For example, when a glide is final, its vocalic reflex does not show up before vowel-initial suffixes, but does appear before consonant-initial suffixes: compare 1sg. matt'e-ko, vs. 3masc.sg. matt'- $a$ 'betray'. Thus, it would seem that in order to determine the frequentative shape with no reference to the root, the input base form is indeterminate and the entire paradigm must be referenced. In contrast, recognizing the underlying root allows one to bypass this problem due to the root realization requirement. No matter which stem is selected as the base, the root glide will surface in the frequentative. 


\subsubsection{Opaque verbs in Gurage}

A paradigm-based hypothesis fares even worse for a language like Chaha, which has rather opaque morphophonology (Prunet 1996b). Related languages such as Muher have gemination of the penultimate consonant in certain conjugations; in Chaha the penultimate consonant is devoiced instead (Banksira 1997, 2000), provided the final stem consonant is sonorant, as seen in the following Type A verbs. The true nature of the root is obscure in the perfective, but can be discerned from an examination of other verb forms.

\begin{tabular}{|c|c|c|c|}
\hline \multicolumn{4}{|l|}{ Chaha } \\
\hline Perfective & Imperfective & Jussive & \\
\hline səpər-ə- & yi-sə $\boldsymbol{\beta}$ ir & yə-s $\boldsymbol{\beta}$ ir & 'break' \\
\hline bətər-ə- & yi- $\beta \partial d i r$ & уə- $\beta \mathbf{d} ə \mathrm{r}$ & 'precede' \\
\hline məkər-ə- & yi-məgir & yə-mgər & 'suppurate' \\
\hline
\end{tabular}

Devoicing is not carried over to the reduplicated consonant in the frequentative. Instead, for those verbs which have underlying voiced consonants, the reduplicated consonant appears as voiced. Recall that the frequentative vowel in Chaha may be [ə] or [a], a lexical choice.

\section{Chaha}

Regular

a. səpər-ə-

'break'

\section{Frequentative}

b. zəkər-ə-

again and again'

Compelling evidence for reference to the root in the frequentative comes from Type B verbs such as j̆akəm-ə- 'hit', which have a devoiced penultimate consonant in the perfective, imperfective and jussive. The frequentative provides the only clue as to the true nature of the underlying root consonant, as devoicing applies to penultimate root segments, but not the reduplicated consonant. Compare this verb with the verb šəkət-ə- 'prepare'.

\section{Chaha}
b. imperfective
jəkəm-ə-
šəkət-ə-
yi-jəkim
yi-šəkit
c. jussive
yə-dəkim
yə-səkit
d. frequentative jigəkəm-ə-
šikakət-ə-

The frequentative reveals that ǰk $\partial m$-ə- has an underlying root consonant $/ \mathrm{g} /$, whereas šəkət-ə- has an underlying /k/ (or /x/ in Banksira's 1997, 2000 
analysis). With no reference to the root, these forms would be impossible to predict based on output-based word-formation alone. Of course, with so few clues as to the underlying root, we might expect this form to level out and for jikəkəm-ə-with a devoiced reduplicative consonant to be attested, and indeed this is a possible alternate form.

Another example from Chaha is difficult to reconcile without reference to the root. Consider the following Type B verbs, characterized by a 'front' element in their initial syllable, either palatalization (19a) or a front vowel (19b). Rose $(1992,1994)$ and Banksira $(1997,2000)$ consider these verbs to be quadriliteral roots, of the shape CyCC. In the jussive of regular verbs, the front element does not surface $(19 \mathrm{c}, \mathrm{d})$. In the frequentative jussive, however, palatalization of the initial consonant does appear (19c).

\begin{tabular}{|c|c|c|c|}
\hline \multicolumn{4}{|l|}{ Chaha } \\
\hline & Imperfective & Frequentative Imperf & ective \\
\hline a. & yi-jəogim & yi-jgagim & 'hit, punch' \\
\hline b. & yi-met' is & yi-mt' $\partial t^{\prime}$ is & 'break the rope' \\
\hline & Jussive & Frequentative Jussive & \\
\hline c. & dəgim & jigəgim & 'hit, punch' \\
\hline d. & mot'is & mit' $\partial t^{\prime}$ 'is & 'break the rope' \\
\hline
\end{tabular}

If the frequentative is derived from the corresponding jussive, it is not clear why palatalization would appear at all in the frequentative in (19c). If, on the other hand, reference is made purely to the root, we would expect all frequentative jussives to appear with a front element, producing *met'at'is instead of mit'at'is (19d). The vowel pattern of the quadriliteral template wins out over the front vowel specification, as we saw for other languages with respect to Type B and Type C verbs. However, there are no restrictions on consonants, and palatalization freely surfaces in the frequentative jussive (19c), despite its nonappearance in the regular jussive. In order for it to do so, the root must be referenced.

\subsubsection{Weak 'a' roots in South Ethio-Semitic}

In South Ethio-Semitic languages, the root is not purely consonantal, but may consist of a vocoid [a], variably analyzed as an underlying /a/ (Banksira 1997, 2000, Rose 1997) or as an abstract pharyngeal segment (Chamora 1997, Prunet 1996a,b, 1998). This segment represents the historical remnant of guttural consonants. The rich inventory of four gutturals $/ 2 \mathrm{~h} \hbar \mathrm{S} /$ in Tigre and Tigrinya has been significantly reduced in the South Ethio-Semitic languages. In Chaha, Muher and Amharic, former guttural consonants in the verbal system are now represented by [a].

Morphologically, the /a/ functions as a root segment (Prunet 1996a,b, 1998). First, reduplication does not occur to fill out surface biconsonantal stems 
that contain [a], ex. basə- 'be worse, bad' or bəzza- 'be abundant' in Muher are not realized as *basas- or *bəzzaz-. This requires speakers to recognize the [a] segment as part of the root (/bas/ and /bza/ respectively), and not a vocalic affix or part of the template. Contrast these verbs with the Type $\mathrm{C}$ verb bazzəz-ə- 'feel gloomy' in Muher, derived from the root /bz/. In this case, the [a] is part of the Type C conjugation. Second, Prunet (1996a, 1998) shows how root /a/ can be the target of rounding in the Inor (Gurage) impersonal verb form if it is centralized to [ə] in the paradigm, whereas other non-root [ə] cannot be rounded. The verb asərə- 'carry on one's back' has the jussive $\partial z \partial r$, where the first [ə] is derived from the root /a/, and the second is part of the vocalic melody of the conjugation. The impersonal is ozari, not *ozori (Prunet 1996a, 1998, Chamora 1997). Similarly, we find the imperfective/impersonal imperfective pair yi-daar / yi-doori 'bless' (root dar) but yi-dars / yidarfi 'break the edge' not *yidorfi (root drs). As pointed out by Prunet (1998), these examples underscore a major problem for analyses such as Ratcliffe (1997) that wish to refer to the root only as a 'phonological unit'. The root /azr/ does not constitute a clear phonological entity, being a combination of a vowel and consonants. Yet speakers must distinguish root [a] from affixal [a].

Furthermore, in order to accurately predict the location of the reduplicative syllable and which consonant is copied in frequentative reduplication, recognizing the /a/ as a root segment is essential. If /a/ is the initial or final root segment, the medial segment is copied, as shown in (19) for Chaha. Recall that the frequentative vowel may be either [a] or [ə] in Western Gurage dialects. Initial /a/ centralizes to [ə] in the frequentative in $(20 \mathrm{a}, \mathrm{b})$.

$\begin{array}{rlll}\text { Chaha } & & & \\ & \text { Regular } & \text { Frequentative } & \\ \text { a. } & \text { agədə- } & \text { əgəgədə- } & \text { 'bind, tie' } \\ \text { b. } & \text { at'əmə- } & \text { ət’ət'əmə- } & \text { 'entice, coax' } \\ \text { c. } & \text { nəsa- }{ }^{12} & \text { nisasa- } & \text { 'pick up' } \\ \text { d. } & \text { gəfa- } & \text { gifəfa- } & \text { 'push' } \\ \text { e. } & \text { wəka- } & \text { wigaka- } & \text { 'pierce' }\end{array}$

A purely word-based approach to weak stem reduplication, with no recognition of the root, would encounter difficulty in identifying the site of the reduplicative syllable. If inserted before the 'penultimate consonant', reduplication of the initial consonant is incorrectly predicted, producing *gigəfa- from (18d) gəfa-, and not the attested gifofa-. If insertion occurs before the 'final stem syllable', then one encounters problems with (a) verbs with final clusters, such as imperfective $y i-k \partial f t$ 'open' (frequentative $y i-k f a f t$ not $* y i-k \partial k \partial f t$ ) and (b) verbs 
with final palatalized consonants such as imperfective $y \dot{i}-f \partial \check{c}$ ' 'grind flour',

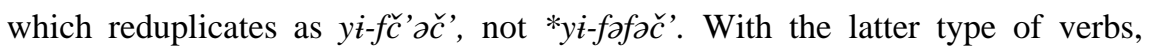
recognizing the root as containing a glide (in this case /ft'y/) allows one to pinpoint the accurate location of the reduplicative syllable: before the penultimate root segment, whether that segment is consonantal or vocalic. Furthermore, it is crucial that the root is a morphological unit and not a phonological unit in order to determine infix placement. ${ }^{13}$ In addition, the same template match requirement with quadriliteral stems is still imposed despite the weak or non-surfacing nature of the root segments, e.g. (20d) gif $f a$-, with the tell-tale [i] of quadriconsonantal stems.

If the medial segment is /a/, such as with the verb /sam/ 'kiss', a problem arises. Copying the /a/ would produce a sequence of three vowels, including the [a] of the infix: sa.a.am-, violating constraints on vowel hiatus. The solution is to copy the initial consonant, as the following Amharic forms reveal. The syllable still occurs before the penultimate root segment, yet further to the left.

\begin{tabular}{|c|c|c|}
\hline Amharic & Regular & Frequentative \\
\hline a. Perfective & sam-ə & sasam-ə $\quad$ 'kiss' \\
\hline b. Imperfective & yì-sim & yí-sasim \\
\hline c. Jussive & yi-sam & yí-sasim \\
\hline
\end{tabular}

The second vowel [i] in the imperfective and jussive forms is the typical [i] of

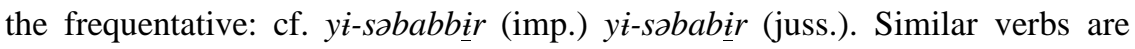
found in Chaha: though typically with a derivational prefix: sam- 'kiss' --> tzsasam- 'kiss repeatedly'. With these examples, it is imperative to recognize that the medial [a] is the penultimate root segment and not simply part of the vocalic melody. As mentioned above, hollow verbs such as Chaha žorz- 'turn around' from root /zwr/ reduplicate as žawawar-, or the Type C verb $y \dot{t}-m^{w} a \check{s}$ 'rub, smear' with frequentative $y \dot{i}-m^{w} \check{s} \check{a} \check{s}$, not $* y \dot{i}-m^{w} \partial m^{w} a \check{s}$.

In summary, a word-based model that dismisses the root would face difficulty in accounting for many of the facts of weak or defective stems in the formation of the frequentative, both in infix placement and in predicting the quality of the reduplicated consonant. Furthermore, a theory that denies the existence of the template by reducing it to general prosodic constraints (Ussishkin 2000a,b) would also face difficulty when dealing with weak roots, where no consistent prosodic shape can be discerned.

\section{Conclusion}


In this article, I have argued that the relationship between regular verbs and the frequentative in Ethio-Semitic requires a derivation using word-based infixation along with superimposition of templatic requirements and reference to the morphological root. This contrasts with other views of word-based Semitic morphology such as Bat-El (1994), Ratcliffe (1997, 1998) and Ussishkin (1999, $2000 \mathrm{a}, \mathrm{b})$ that reject the root as unnecessary. The addition of the frequentative infix triggers a templatic shape requirement for stems with four or five consonants. This overrides many properties of the regular verb stem. In addition, in South Ethio-Semitic, the frequentative crucially requires reference to the root to determine location of the infix. The derivation of the frequentative argues for a theory of Semitic morphology that does not make a clear distinction between word-based and root-based derivation.

\section{Notes}

* Many thanks to my consultants: Mussie Bakit (Tigre), Hiwet Asmelash, Beraki Woldeabzghi and Alem Woldemariam (Tigrinya), Farida Towfik (Harari), Tadesse Sefer and Wolde Fujie (Chaha), Badarga Tadele and Mekebeb Fikadu (Muher). I am grateful to Joseph Shimron for inviting me to submit this paper to the volume. I thank him and an anonymous reviewer for useful discussion and comments on this paper. This project was sponsored by grants from the UCSD Academic Senate.

${ }^{1}$ Ethiopian Semitic or Ethio-Semitic are linguistic designations describing the branch of Semitic languages spoken in Ethiopia and Eritrea. In the past, this term was also geographically accurate as the languages were spoken within the borders of Ethiopia. Today, Tigre is spoken within Eritrea, and Tigrinya is spoken both in Eritrea and northern Ethiopia.

${ }^{2}$ All verbs are given in the 3 rd person masculine singular perfective form unless otherwise specified. ). Like other Semitic languages, inflectional markers for subject are expressed as suffixes in the perfective (3masc.sg. -ə or -a/-a: depending on the language), whereas inflectional subject affixes in other tenses are a combination of prefixes and suffixes. These inflectional markers have no bearing on the form of the frequentative. In Tigrinya, the past tense is usually rendered by the gerundive form: sabiru and not the perfective sabara. I use the perfective here to facilitate comparison with other languages.

${ }^{2}$ In Tigre, the Type A stem has the shape CəCC- with vowel-initial suffixes, but CəCəC- with consonant-initial ( $g \partial f r-a$ 'he whipped' vs. gəfər-ko 'I whipped'), unless there is a medial guttural consonant. I note the vowel of the $3 \mathrm{~ms}$ subject marker in Tigre as [a:]. This vowel triggers the lowering of all preceding [ə] to [a], up to an intervening peripheral vowel. See Palmer (1956), Raz (1983), Lowenstamm \& Prunet (1985), Rose (1996). I do not indicate this lowering in 
this article. The length difference in Tigrinya is controversial (see Buckley 1997 for discussion), but not so for Tigre, where there are distinct minimal pairs.

${ }^{4}$ Similar arguments to those presented in this article are discussed in Rose (to appear) for Tigre.

${ }^{5}$ In the sample of languages discussed in this paper, Chaha and Harari do not have surface gemination in the verb system, although see Banksira (1997) for assumptions about underlying gemination in Chaha that is neutralized on the surface.

4 In Chaha, Muher and Harari, the parallel is not found in the jussive/imperative shape. The regular quadriliteral has the shape CəCCC, with epenthesis, e.g. maskir. The frequentative has the shape $\mathrm{CCaCC}$ (or $\mathrm{CC} ə \mathrm{CC}$ ), not the expected CəCaCiC: sibabir*sababir. I hypothesize that the absence of the initial [ə] vowel is due to a general requirement in these languages that the jussive/imperative be equally or less 'specified' than the imperfective with respect to gemination and vowel melodies. Typically the two forms differ by position of an [ə] vowel (ex. Harari imp. -sabir-/ juss. -sibar- 'break'), by less vowel specification in the jussive (ex. Chaha imp. -saßir- / juss. -sißßir- 'break' ) or by gemination in the imperfective and lack of it in the jussive (ex. Muher imp. -marrix- / juss. marix- 'capture prisoner'). Note that Amharic requires all quadriliteral shapes to have [ə] between the first two consonants in all forms, but Chaha, Muher and Harari do not, allowing an epenthetic vowel.

${ }^{7}$ I am referring to 'root segments' rather than 'consonants' since in South EthioSemitic languages, roots are not entirely consonantal, but may include the vowel /a/. See section 3.2.3.

${ }^{8}$ It is conceivable that templatic shapes can be derived via alignment constraints (see Buckley 1997 on Tigrinya, Ussishkin 1999 on Modern Hebrew). I do not attempt to provide such an analysis here, but underscore that the shapes are specific not only to the number of consonants, but also the lexical requirements of the verb. Type B verbs use the same basic templates, but the middle two consonant slots form a geminate: wallab- (perf.) vs. -wallib- (imperf./juss.). Note that Type A verbs typically distinguish the imperfective and jussive: $-\mathrm{C} ə \mathrm{C}(\mathrm{C}) \mathrm{iC}-$ vs. -CCəC-.

${ }^{9}$ I do not explore this idea further in this paper, but there seems to be a correlation between the ability to create longer reduplicative verbs and the independent existence of suitable templates in Ethiopian Semitic. See Unseth (1998) for similar observations.

${ }^{10}$ This is a Type B verb with a final glide [y], which does not appear in the $3 \mathrm{~ms}$ form: matt'-a. In the 1s form, it appears as [e]: matt'e-ko, Frequentative: mət'a:t'e-ko. 
${ }^{11}$ Two verbs of this shape, s'om- $a$ : 'fast' and mot-a: 'die' reduplicate with a [y] glide instead of the expected [w] glide: səya:yəm-a: 'fast intermittently' not

*sawa:wəm-a:. This may be attributed to the presence of a labial consonant in the root, in both cases [m]. While glides usually form a class apart from other consonants in root structure constraints (Greenberg 1950, McCarthy 1994), Ussishkin (1999) has found similar restritions on the combination of coronals and the palatal glide [y] in Modern Hebrew in the derivation of denominal verbs. It would appear that constraints on [labial] are overtaxed by having three labial consonants in the frequentative stem, and the [y] consonant is substituted instead of $[w]$. However, alternations between [w] and [y] are also found in Tigrinya with no apparent trigger (Berhane 1991): Sanəwə or Sanəyə ruined' and in Ammani Arabic (Zaweydeh \& Davis 1999a,b): ex. Sawad-a 'return' corresponds to the name Sayda.

${ }^{12}$ The sequence [a-ə] is fused to [a], so vocalic ə-initial suffixes lose their initial vowel: ex. /nəsa-ə/ --> [nəsa] 'he picked up' or /nəsa-əma/ --> [nəsama] 'the (fem.pl.) picked up'.

${ }^{13}$ An alternate analysis would allow association of the root to a template at an intermediate level in the derivation of the regular verb, and then allow insertion of the reduplicative syllable to the template rather than by reference to root segments. This approach also recognizes a morphological root, but would require establishing a connection to the regular verb at a more abstract level.

\section{References}

Angoujard, Jean-Pierre. 1988. "Gémination et redoublement." Langues Orientales, Ancienne Philologie et Linguistique 1.1-15.

Angoujard, Jean-Pierre \& Michel Denais. 1989. "Le pluriel brisé en tigrigna." Langues Orientales, Ancienne Philologie et Linguistique 2.99-148.

Banksira, Degif Petros. 1997. The sound system of Chaha. Ph.D. Dissertation, Université du Québec à Montréal

Banksira, Degif Petros. 2000. Sound mutations: the morphophonology of Chaha. Amsterdam \& Philadelphia: John Benjamins.

Bat-El, Outi. 1994. "Stem modification and cluster transfer in Modern Hebrew." Natural Language and Linguistic Theory 12.571-596.

Benmamoun, Elabbas. 1999. "Arabic morphology: The central role of the imperfective." Lingua 108.175-201.

Berhane, Girmay. 1991. Issues in the phonology and morphology of Tigrinya. Ph.D. Dissertation, Université du Québec à Montréal.

Buckley, Eugene. 1990. "Edge-in association and OCP 'violations' in Tigrinya." Proceedings of WCCFL 9.75-90. 
Buckley, Eugene. 1997. "Against vowel length in Tigrinya." Studies in African Linguistics 26.1.63-102.

Chamora, Berhanu. 1997. The Phonology of Inor Verbs. M.A. Thesis, Université du Québec à Montréal.

Gafos, Diamandis. 1998. "Eliminating Long-Distance Consonantal Spreading." Natural Language and Linguistic Theory 16.223-278.

Goldenberg, Gideon. 1994. "Principles of Semitic Word-Structure." Semitic and Cushitic Studies, ed. by G. Goldenberg \& S. Raz, 29-64. Wiesbaden: Harrassowitz.

Greenberg, Joseph. 1950. "The Patterning of Root Morphemes in Semitic." Word 6, 162-181.

Hammond, Michael. 1988. "Templatic Transfer in Arabic Broken Plurals." Natural Language and Linguistic Theory 6.247-270.

Heath, Jeffrey. 1987. Ablaut and Ambiguity: Phonology of a Moroccan Arabic Dialect. Albany, NY: State University of New York Press.

Leslau, Wolf. 1939. "Le thème verbal fréquentatif dans les langues éthiopiennes." Revue des études sémitiques et bablyloniaca 15-31.

Leslau, Wolf. 1941. Documents tigrigna (éthiopien septentrional). Paris: Klincksieck

Leslau, Wolf. 1995. Reference Grammar of Amharic. Wiesbaden: Harrassowitz.

Lowenstamm, Jean \& Jean-François Prunet. 1985. "Tigre Vowel Harmonies." Paper presented at the 16th Annual Conference on African Linguistics. Yale University.

McCarthy, John. 1979. Formal Problems in Semitic Phonology and Morphology. Doctoral dissertation, MIT.

McCarthy, John. 1981. "A Prosodic Theory of Non-concatenative Morphology." Linguistic Inquiry 12, 373-418.

McCarthy, John. 1994. "The phonology and phonetics of Semitic pharyngeals." Phonological structure and phonetic form: papers from Laboratory Phonology III, ed. by P. Keating, 191-234. Cambridge: Cambridge University Press.

McCarthy, John \& Alan Prince. 1986. "Prosodic morphology." Manuscript, Brandeis University and University of Massachusetts, Amherst.

McCarthy, John \& Alan Prince. 1990a. "Foot and word in Prosodic Morphology: The Arabic broken plural." Natural Language and Linguistic Theory 8.209-282.

McCarthy, John \& Alan Prince. 1990b. "Prosodic Morphology and Template Morphology." Perspectives on Arabic Linguistics II. Papers from the Second Annual Symposium on Arabic Linguistics, ed. by M. Eid, \& J. McCarthy, 1-54. Amsterdam and Philadelphia: John Benjamins.

Palmer, F.R. 1962. The morphology of the Tigre noun. London: Oxford University Press. 
Petros (Banksira), Degif. 1993. La dérivation verbale en chaha. M.A. Thesis. Université du Québec à Montréal.

Prunet, Jean-François. 1996a. "Guttural vowels." Essays in Gurage Language and Culture, ed. by Grover Hudson, 175-203. Wiesbaden: Harrasowitz.

Prunet, Jean-François. 1996b. "Some Core Properties of Semitic Morphology: Evidence from the Far South." Current Trends in Phonology, ed. by J. Durand \& B. Laks, 617-162. Salford: European Studies Research Institute, University of Salford Publications.

Prunet, Jean-François. 1998. "When vowels function like consonants." In Phonological Studies 1, ed. by The Phonological Society of Japan, 219226. Tokyo: Kaitakusha.

Prunet, Jean-François \& Degif Petros (Banksira). 1996. "L'interaction entre schème et racines en chaha." Studies in AfroAsiatic grammar, ed. by J. Lecarme, J. Lowenstamm \& U. Shlonsky, 302-336. The Hague: Holland Academic Graphics.

Prunet, Jean-François, Renée Béland, \& Ali Idrissi. 2000. "The Mental Representation of Semitic Words" Linguistic Inquiry 31.609-648.

Ratcliffe, Robert. 1997. "Prosodic Templates in a Word-Based Morphological Analysis of Arabic." Perspectives on Arabic Linguistics X. Papers from the Tenth Annual Symposium on Arabic Linguistics. ed. by M. Eid. \& R. Ratcliffe, 147-171. Amsterdam and Philadelphia: John Benjamins.

Ratcliffe, Robert. 1998. The 'Broken' Plural Prolem in Arabic and Comparative Semitic: allomorphy and analogy in non-concatenative morphology. Amsterdam studies in the theory and history of linguistic science. Current Issues in Linguistic Theory v. 168. Amsterdam and Philadelphia: John Benjamins.

Raz, Shlomo. 1983. Tigre grammar and texts. Malibu: Undena Publications.

Rose, Sharon. 1992. De la palatalisation en chaha. M.A. Thesis. Université du Québec à Montréal.

Rose, Sharon. 1994. "The Historical development of palatalization in Gurage." Proceedings of the $20^{\text {th }}$ Annual Meeting of the Berkeley Linguistics Society, Special Session on Historical Issues in African Linguistics, ed. by K. Moore, D. Peterson \& C. Wentum, 112-124.

Rose, Sharon. 1996. "Variable Laryngeals and Vowel Lowering." Phonology 13.73-117.

Rose, Sharon. 1997. Theoretical issues in comparative Ethio-Semitic phonology and morphology. Ph.D. Dissertation, McGill University.

Rose, Sharon. to appear. "Triple Take: Tigre and the case of internal reduplication." Research in Afroasiatic Grammar, ed. by R. Hayward, J. Ouhalla, D. Perrett. Amsterdam and Philadelphia: John Benjamins.

Rose, Sharon. 2000. "Multiple correspondence in reduplication." Proceedings of $23^{\text {rd }}$ Annual Meeting of the Berkeley Linguistics Society, ed. by M. Juge \& J. Moxley, 315-326. 
Unseth, Pete. 1998. Bi-Consonantal Reduplication in Semitic: An Initial Survey of "Quinquiliterals" and Related Forms (especially in Ethiopian Semitic). Paper given at the $26^{\text {th }}$ North American Conference on Afroasiatic Linguistics.

Ussishkin, Adam. 1999. "The inadequacy of the consonantal root: Modern Hebrew denominal verbs and output-output correspondence." Phonology 16.401-442

Ussishkin, Adam. 2000a. "Root-and-Pattern Morphology without Roots and Patterns." Proceedings of NELS 30, ed. by M. Hirotani, A. Coetzee, N. Hall, J.-Y. Kim, 655-670. GLSA, UMass Amherst.

Ussishkin, Adam. 2000b. The Emergence of Fixed Prosody. Doctoral Dissertation, University of California, Santa Cruz.

Zawaydeh, Bushra \& Stuart Davis. 1999a. "Hypocoristic formation in AmmaniJordanian Arabic." Perspectives on Arabic linguistics XII, Papers from the Twelfth Annual Symposium on Arabic Linguistics, ed. by E. Benmamoun. Amsterdam and Philadelphia: John Benjamins.

Zawaydeh, Bushra \& Stuart Davis. 1999b. "Hypocoristic patterns in colloquial Arabic and the status of the consonantal root." Paper given at the Semitic Morphology Workshop, University of Illinois, Urbana-Champaign. 